\title{
The role of the gut microbiome in graft fibrosis after pediatric liver transplantation
}

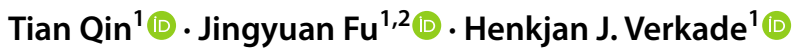

Received: 22 June 2020 / Accepted: 29 August 2020 / Published online: 13 September 2020

(c) The Author(s) 2020

\begin{abstract}
Liver transplantation (LT) is a life-saving option for children with end-stage liver disease. However, about $50 \%$ of patients develop graft fibrosis in 1 year after LT, with normal liver function. Graft fibrosis may progress to cirrhosis, resulting in graft dysfunction and ultimately the need for re-transplantation. Previous studies have identified various risk factors for the postLT fibrogenesis, however, to date, neither of the factors seems to fully explain the cause of graft fibrosis. Recently, evidence has accumulated on the important role of the gut microbiome in outcomes after solid organ transplantation. As an altered microbiome is present in pediatric patients with end-stage liver diseases, we hypothesize that the persisting alterations in microbial composition or function contribute to the development of graft fibrosis, for example by bacteria translocation due to increased intestinal permeability, imbalanced bile acids metabolism, and/or decreased production of short-chain fatty acids (SCFAs). Subsequently, an immune response can be activated in the graft, together with the stimulation of fibrogenesis. Here we review current knowledge about the potential mechanisms by which alterations in microbial composition or function may lead to graft fibrosis in pediatric LT and we provide prospective views on the efficacy of gut microbiome manipulation as a therapeutic target to alleviate the graft fibrosis and to improve long-term survival after LT.
\end{abstract}

$\begin{array}{ll}\text { Abbreviations } \\ \text { ALD } & \text { Alcoholic liver disease } \\ \text { BMI } & \text { Body-mass index } \\ \text { DAMP } & \text { Damage-associated molecular pattern } \\ \text { DSA } & \text { Donor-specific antibody } \\ \text { ECM } & \text { Extracellular matrix } \\ \text { FMT } & \text { Fecal microbiota transplant } \\ \text { FXR } & \text { Farnesoid X receptor } \\ \text { HSC } & \text { Hepatic stellate cell } \\ \text { IRI } & \text { Ischemia-reperfusion injury } \\ \text { LT } & \text { Liver transplantation } \\ \text { LPS } & \text { Lipopolysaccharide } \\ \text { NAFLD } & \text { Non-alcoholic fatty liver disease }\end{array}$

Jingyuan Fu and Henkjan J. Verkade have shared last authorship.

Henkjan J. Verkade

h.j.verkade@umcg.nl

1 Pediatric Gastroenterology/Hepatology, Section of Nutrition and Metabolism, Research Laboratory of Pediatrics, Department of Pediatrics, Beatrix Children's Hospital/ University Medical Center Groningen, P.O. Box 30.001, 9700 RB Groningen, The Netherlands

2 Department of Genetics, University of Groningen, University Medical Center Groningen, Hanzeplein 1, 9713 GZ Groningen, The Netherlands

$\begin{array}{ll}\text { NF-kB } & \text { Nuclear factor kappa B } \\ \text { PAMP } & \text { Pathogen-associated molecular pattern } \\ \text { PRR } & \text { Pattern recognition receptor } \\ \text { PTLD } & \begin{array}{l}\text { Post-transplantation lymphoproliferative } \\ \text { disease }\end{array} \\ \text { SCFA } & \text { Short-chain fatty acid } \\ \text { TGF } \beta & \text { Transforming growth factor } \beta \\ \text { TLR } & \text { Toll-like receptor }\end{array}$

\section{Introduction}

Pediatric liver transplantation (LT) has become a standard procedure for children with end-stage liver disease, for example due to biliary atresia or progressive familial intrahepatic cholestasis. The number of LTs performed globally has been reported to be 4 to 9 per million population younger than 18 years, with a 10-year survival rate higher than $80 \%$ (Bourdeaux et al. 2009; Fischler et al. 2019).

Notwithstanding the high survival rate of LTs, up to $50 \%$ of pediatric LT patients develop graft fibrosis in 1 year after transplantation, based on protocol biopsies. (Evans et al. 2006; Scheenstra et al. 2009). Liver fibrosis is a well-known consequence of chronic liver injury occurring in a variety of liver diseases, including genetic diseases, hepatitis, and 
metabolic diseases. Fibrosis is pathophysiologically considered as a wound healing response in reaction to repeated liver injury, leading to progressive accumulation of extracellular matrix (ECM). Interestingly, pediatric patients with post-transplant graft fibrosis frequently do not have clear indications of graft complications or of (prior or ongoing) elevations in liver biochemistry, in contrast to conditions leading to liver fibrosis before LT. Thereby, graft fibrosis can be considered as a "silent fibrosis". The clinical consequence of graft fibrosis is not well known, but $29 \%$ of patients with graft fibrosis can progress to cirrhosis, which may result in graft dysfunction and ultimately the need for re-transplantation (Scheenstra et al. 2009). Therefore, understanding the underlying risk factors of graft fibrosis is clinically important.

Many factors have epidemiologically been associated with graft fibrosis, including donor age, prolonged ischemia time, transplant-related or immune-related factors such as biliary/vascular complications, subclinical rejection, and post-transplantation lymphoproliferative diseases (PTLD) (Chanpong et al. 2019; Rhu et al. 2020; Scheenstra et al. 2009; Tokodai et al. 2018; Ueno et al. 2016). However, these factors do not provide a satisfactory explanation for the high incidence of graft fibrosis nor the underlying mechanisms.

The intestinal microbiota in a human adult consists of $10^{13}-10^{14}$ microorganisms and has been shown to play an active role in many aspects of health and disease (Lynch and Pedersen 2016; Sender et al. 2016; Valdes et al. 2018). Microbial dysbiosis refers to an "imbalance" in the gut microbial community that is associated with diseases, which is often characterized as lower diversity, an increase of potentially pathogenic taxa, and a decrease of beneficial taxa when compared to a healthy microbiota. The crosstalk between the gut and liver is increasingly being recognized (Albillos et al. 2020; Tripathi et al. 2018). Microbial dysbiosis could be complicit in liver disease progression and has long been associated with various liver diseases, such as nonalcoholic fatty liver disease (NAFLD) (Boursier et al. 2016; Schwimmer et al. 2019; Zhu et al. 2013), alcoholic liver disease (ALD) (Bajaj 2019), cirrhosis and its complications (Chen et al. 2011). Animal studies have demonstrated the transferrable phenotype of NAFLD (Yuan et al. 2019) and ALD (Llopis et al. 2016) via the transplantation of disease-associated fecal microbiota (fecal microbiota transplant, FMT). Reversely, modulation of the microbiota could help ameliorate liver injury (Dhiman et al. 2014; Liu et al. 2019). These observations support a causal contribution of microbiota to the pathogenesis of liver diseases. Furthermore, the gut microbiome has been reported to influence the success rate of solid organ transplantation, including renal and intestinal transplantation (Ardalan and Vahed 2017; Chenyang Wang 2018), and hematopoietic stem cell transplantation (Peled et al. 2020).
From a perspective view, we herewith hypothesize that the gut microbiome is an important determinant for the development of liver graft fibrosis and that restoration/ manipulation of the gut microbiome after pediatric LT can mitigate or even prevent post-LT graft fibrosis. Microbial dysbiosis is already present in pediatric patients with endstage liver diseases. Due to the cross-talk along the gutliver axis, we expect a feed-back regulation between the gut microbiota and the liver. After LT, altered microbial composition and/or function can be ameliorated or even reversed due to the restoration of liver function. In turn, balanced gut microbiome is essential to maintain normal liver function. However, the microbial composition/function may not be fully restored after LT. If alterations persist post-transplantation, we hypothesize that they contribute to the development of graft fibrosis. This review aims to provide an overview of graft fibrosis after pediatric LT, to summarize the current-ofstate discoveries of the gut microbial associations before and after LT, to discuss potential mechanisms underlying the role of the gut microbiome in the development of graft fibrosis, and to suggest microbiome-targeted approaches to alleviate fibrosis. Finally, we propose an experimental framework to explore this perspective.

\section{Graft fibrosis after pediatric LT}

According to the primary location in the hepatic acinus, graft fibrosis has been differentiated into portal, sinusoidal and centrilobular fibrosis (Venturi et al. 2014). The different locations of fibrosis have been associated with different biochemical profiles and risk factors. Portal fibrosis has been correlated with abnormal liver function, prolonged ischemia time, deceased donor grafts, and a history of PTLD or rejection while sinusoidal fibrosis was related to biliary complications and abnormal liver function (Baas et al. 2017; Rhu et al. 2020; Venturi et al. 2014). Centrilobular fibrosis was associated with vascular complications, presence of autoantibodies, gamma-globulins levels, donor factors, and history of PTLD (Rhu et al. 2020; Venturi et al. 2014). Autoantibodies are immunoglobulins that recognize host antigens and commonly associate with chronic liver injury. The presence of centrilobular inflammation and fibrosis therefore would suggest some form of chronic rejection in the allograft (Egawa et al. 2012; Hassoun et al. 2004; Sundaram et al. 2006). Baas et al. (2017) confirmed the high prevalence of fibrosis post-LT and reported associations of the three acinar locations of fibrosis with different clinical variables, indicating different mechanisms involving in graft fibrosis. For example, chronic, low-grade rejection could be involved in the development of graft fibrosis (Feng et al. 2018; Yamada et al. 2012). Graft rejection is mediated via pathways of allorecognition, the processing and presentation of donor 
antigens to recipient cells. Especially, chronic rejection can contribute to graft injury via antibody-mediated or T cellmediated mechanisms (Lee 2017; Tedesco and Grakoui 2018).

Several observations do support the contribution of antibody-mediated immunity processes to the development of fibrosis. For example, donor-specific antibodies (DSA), either present before transplantation or de novo generated after transplantation, is associated with both chronic rejection and graft fibrosis (Jackson et al. 2020; Miyagawa-Hayashino et al. 2012; Tokodai et al. 2018). Post-transplant de novo DSA are associated with a highly mismatched graft and/or with under-immunosuppression (Zhang 2018). According to this concept, increasing immunosuppression would be expected to inhibit graft rejection and thereby attenuate fibrosis in pediatric LT patients. However, the benefit of increasing immunosuppression on graft histological results has not been unequivocally clear. Evans et al. reported that steroid therapy decreased histological hepatitis, but not the degree of fibrosis (Evans et al. 2006; Venturi et al. 2014). In a long-term follow-up trial focused on pediatric LT (Scheenstra et al. 2009), the graft fibrosis was not significantly correlated to either rejection or chronic hepatitis, nor to the presence of a calcineurin inhibitor in the immunosuppressive regimen. Finally, the presence of DSA, as a marker of alloimmunity, has not been confirmed in all studies as a predictor of the development of fibrosis. Vandevoorde et al. described in patients at 10 years post-LT that severe fibrosis was present in $11.1 \%$ of DSA-positive and $10.3 \%$ of DSA-negative patients (Vandevoorde et al. 2018). Thus, although immune phenomena may play a role in graft fibrosis, its precise function and mechanism, as well as its relative contribution to other factors is still unclear.

As indicated above, prolonged cold and warm ischemia time was reported as risk factor for portal graft fibrosis after pediatric LT (Chanpong et al. 2019; Scheenstra et al. 2009; Venturi et al. 2014). Ischemia-reperfusion injury (IRI) has long been recognized to induce the release of endogenous molecules from apoptotic and necrotic cells, named dangeror death-associated molecular patterns (DAMPs), which may play a role in fibrogenesis (Mihm 2018). However, it is not clear whether this IRI is indeed mechanistically involved in "silent" graft fibrosis detected by protocol biopsies years after transplantation. Similarly, the mechanisms by which high donor age, partial grafts or deceased donor organs specifically contribute to a higher prevalence of graft fibrosis after pediatric LT has not been resolved. (Chanpong et al. 2019; Scheenstra et al. 2009; Venturi et al. 2014). In summary, much of the research up to now has been descriptive in nature, displaying argumentative results and thus the risk factors indicated above still need elucidation of the pathogenic mechanisms.
Altered microbial composition/function in patients undergoing LT

Pediatric patients with end-stage liver diseases, such as due to biliary atresia or other cholestatic diseases, often have an altered microbial composition (Guo et al. 2018; Wang et al. 2020a; Wang et al. 2019). Such alteration in the microbiome would possibly lead to gut barrier disruption, to bacterial translocation and to triggering of the host's immune and metabolic responses in the liver (De Minicis et al. 2014; Fouts et al. 2012). For instance, infants with biliary atresia have lower microbial diversity and higher intestinal permeability than healthy infants (Wang et al. 2020a). In particular, patients showed a decrease in the relative abundance of genera which are considered beneficial, i.e., Bifidobacterium and Faecalibacterium (Guo et al. 2018; Wang et al. 2019), as well as an imbalance in the components of bile acids (Wang et al. 2019). The surgical procedure of LT may temporarily increase the intestinal permeability and allow some pathogenic bacteria to enter the portal or systemic circulation and initiate the immune response (Okumura and Takeda 2018). The administration of prophylactic antibiotics and of immunosuppressants at the perioperative and early post-LT period can also decrease microbial diversity (Kato et al. 2017; Lu et al. 2013) and induce colonization of multidrug-resistance bacteria (Annavajhala et al. 2019), contributing to the risk of postLT infections. Antibiotic treatment showed various effects on intestinal permeability upon using different antibiotic classes (Tulstrup et al. 2015). Mice with long-term exposure to low doses of penicillin, exhibited accelerated fibrogenesis in response to a high-fat diet compared with control mice, indicating that the combination of antibiotics and a high-fat diet increased liver fibrosis in an NAFLD model (Mahana et al. 2016). Similarly, in mouse models of chronic liver injury, liver fibrosis was more common in germ-free mice than in conventional mice (Mazagova et al. 2015). These data suggested that existence of hepatoprotective microbiota might help prevent or mitigate liver fibrosis in vivo. In human studies, rifaximin, a non-absorbable antibiotic commonly used in advanced liver diseases, may exert beneficial impact by shifting the microbial functionality (Ponziani et al. 2015). One clinical trial of rifaximin has been proposed to assess the effect of gut microbiota on liver fibrosis in humans, however results have not yet been published (Madsen et al. 2018).

\section{Restoration of altered microbial composition/ function by LT}

So far, studies on the microbial response to LT are scarce in pediatric patients. Several LT studies in adults have suggested that LT positively impact on the gut microbiome by improving the microbial diversity and composition (Table 1). For instance, Sun et al. assessed fecal microbiome 
in pre-LT and post-LT fecal samples from 9 LT patients, as well as in 15 healthy controls (Sun et al. 2017). They found that the microbiome in pre-LT patients was significantly different from that in post-LT ones and in healthy controls, while no significant difference observed between the latter two groups. This study provides indications that LT, at least partially, restores the composition of the intestinal microbial community. Compared to pre-LT samples, the post-LT microbiome showed a decrease in the relative abundances of Actinobacillus, Escherichia and Shigella, but an increase in the abundance of Micromonosporaceae and Akkermansia. Interestingly, Akkermansia muciniphila is associated with gut-barrier integrity and the reduction in the abundance of A. muciniphila was correlated with thinning of the mucus layer and increased liver inflammation (Everard et al. 2013; Grander et al. 2018; Wu et al. 2017). Similarly, Bajaj et al. (2017, 2018a) also showed that LT increased microbial diversity, decreased potentially pathogenic bacteria taxa, such as the genera belonging to Enterobacteriaceae, and increased potentially beneficial taxa, such as Ruminococcaceae, along with amelioration in cognition and life quality of patients.

\section{Contribution of altered microbial composition/ function to graft fibrosis}

Generally speaking, LT has a positive impact on the gut microbiome (Bajaj et al. 2017, 2018a; Sun et al. 2017) (Table 1). However, some post-LT patients may display persistently altered microbial composition/function, which in turn influences the liver (Bajaj et al. 2017; Lu et al. 2019). Below we discuss several potential underlying mechanisms through which persistently altered microbial composition/ function could contribute to the risk of post-LT graft fibrosis (Fig. 1).

\section{Translocation of PAMPs due to higher intestinal permeability}

One mechanism could be that altered microbial composition results in impaired gut barrier integrity, increases the translocation of microbes and microbial products across the gut epithelium, such as pathogen-associated molecular patterns (PAMPs) (Fouts et al. 2012). With increased intestinal permeability, harmful pathogens and/or products originating from the gut lumen travel across the gut barrier and reach the local mesenteric lymph nodes, which are unable to provide an adequate clearance when the amount of translocated PAMPs surpasses their surveillance activity (Albillos et al. 2020; Fouts et al. 2012). In that condition, translocated microbes and their products can translocate to the liver through the portal vein, initiating and aggravating an innate immune activation in the transplanted organ (Seki and Schnabl 2012) (Fig. 2).

PAMPs, i.e., lipopolysaccharide (LPS), microbial DNA, peptidoglycans, and lipopeptides, are then recognized via pattern recognition receptors (PRRs) in the liver (Chen et al. 2019; Seki et al. 2007). Toll-like receptors (TLRs), which are expressed in all cell types in the liver, are the most studied PRRs. The interaction between PAMPs and TLRs elicits host immunological responses via Kupffer cells, either MyD88-dependent or MyD88-independent, resulting in the activation of nuclear factor-kappa $\mathrm{B}(\mathrm{NF}-\kappa \mathrm{B})$ and the production of inflammatory cytokines and chemokines (Seki et al. 2007). As such, the downstream inflammasome-mediated pathways (e.g., TGF $\beta$ signaling) stimulate the synthesis of ECM by hepatic stellate cells (HSCs), potentially leading to hepatic inflammation and fibrosis. Several TLR deficient mouse strains or cells were protected against liver injury and fibrosis (Gabele et al. 2008; Hartmann et al. 2012; Seki et al. 2001, 2007), supporting the importance of microbiota in mediating liver fibrogenesis.

\section{Imbalanced bile acid metabolism}

Bile acids form a class of cholesterol-derived amphipathic compounds that circulate between the gut and the liver in the so-called enterohepatic circulation. Bile acids have important physiological roles in dietary lipid absorption, microbiome modulation, metabolism, liver function, and bile production (de Boer et al. 2018). A healthy bile acid metabolism requires both hepatic and microbial metabolism and indeed, an altered microbial composition has been associated with corresponding changes in bile acid level or composition (Sayin et al. 2013; Wang et al. 2020b). Bile acids are the endogenous ligands of farnesoid X receptor (FXR), a nuclear bile acid receptor, which enhances the epithelial barrier integrity (Gadaleta et al. 2011) and provides negative feedback on hepatic de novo bile acids synthesis ( $\mathrm{Li}$ et al. 2017; Schumacher et al. 2020). Studies showed that FXR agonists exert an anti-fibrotic role in animal models via suppression of NF- $\mathrm{\kappa B}$ signaling (Verbeke et al. 2016; Wang et al. 2008). Imbalance of so-called primary (i.e., synthesized by the liver) and secondary (i.e., having undergone structural modifications by the intestinal microbiome) bile acids might exert regulatory effects on the liver inflammatory response and the gut barrier function via FXR signaling. Interestingly, in a recent study, the administration of probiotics to restore intestinal microbial composition could mitigate the liver fibrosis through inhibiting FXR mediated hepatic bile acid synthesis (Liu et al. 2019). 


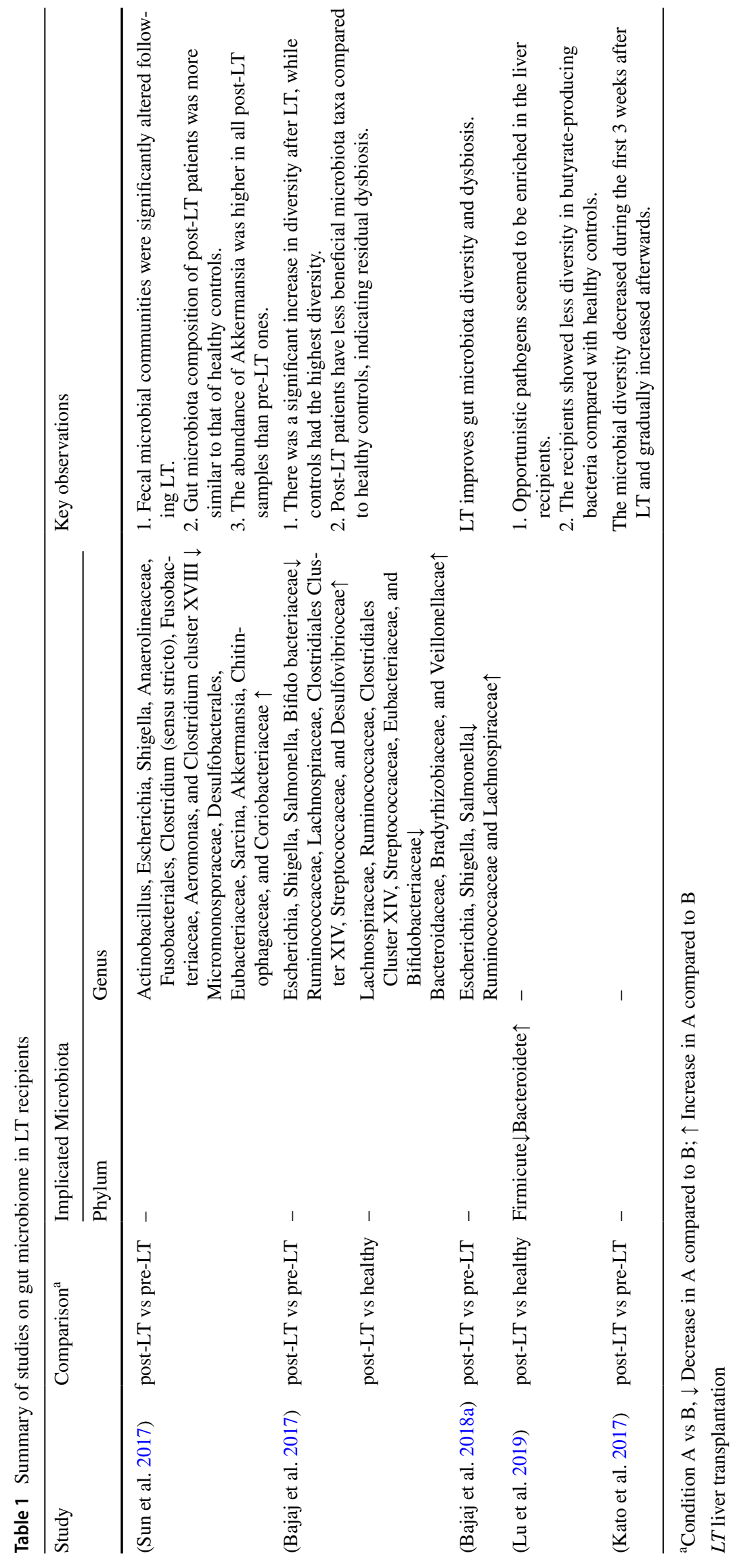




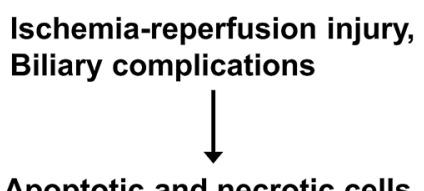

Apoptotic and necrotic cells

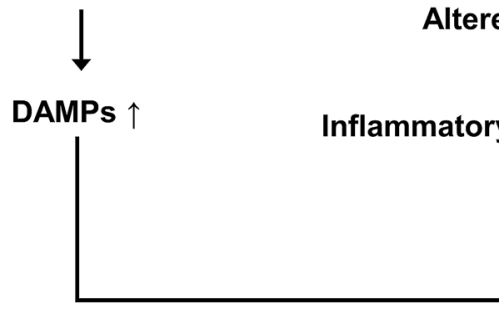

Altered microbial composition/function

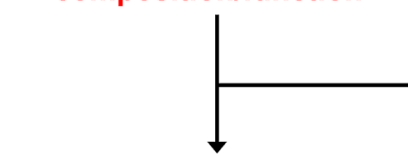

Altered SCFAs

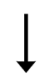

$\downarrow$

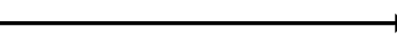

Intestinal permeability $\uparrow$

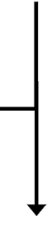

Altered intestinal bile acids

PAMPs $\uparrow$

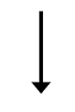

FXR signaling $\downarrow$ ?

in liver and intestine

Kupffer cells activation TLR

TGF $\beta$

HSCs activation

$\downarrow$ ECM accumulation

Liver inflammation/fibrosis

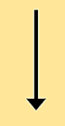

Bile acid synthesis $\uparrow$ NF-kB signaling $\uparrow$
Fig. 1 Possible mechanisms of persistent dysbiosis in liver fibrosis. DAMP damage-associated molecular pattern, ECM extracellular matrix, FXR farnesoid $\mathrm{X}$ receptor, $P A M P$ pathogen-associated molec- ular pattern, $S C F A$ short-chain fatty acid, $T G F \beta$ transforming growth factor $\beta, T L R$ toll-like receptor

\section{Decreased production of short-chain fatty acids (SCFAs)}

SCFAs, including acetate, propionate and butyrate, are the main end products after degradation of dietary fiber by gut microbiota and have several beneficial impacts on host health. SCFAs have an important role in maintenance of host intestinal barrier integrity (Wang et al. 2012), the immune system and metabolism (Bach Knudsen et al. 2018; Mörkl et al. 2018; Schulthess et al. 2019). The immune regulatory function of SCFAs has been described in several studies, which involves the activation of NF- $\mathrm{KB}$ signaling, the production of proinflammatory cytokines and the activity of regulatory T-cells (Tregs) (Arpaia et al. 2013; Smith et al. 2013; Usami et al. 2008). Fecal and circulating SCFAs have immunomodulatory functions, and have been related to type 2 diabetes, inflammatory bowel diseases and NAFLD (Ding et al. 2019; Müller et al. 2019; Parada Venegas et al. 2019). Supplementing dietary of SCFAs or stimulating SCFA producing bacteria via probiotic approaches could have therapeutic effects (Segain et al. 2000; Weitkunat et al. 2017). Microbial dysbiosis could also be characterized by the reduction of SCFA producing microbiota, which is also indicated in adult LT recipients (Lu et al. 2019). If alteration in microbial composition/function was not restored postLT, several vital functions of SCFAs for the host, including maintaining intestinal barrier integrity and immune regulation, can be disrupted, which could subsequently lead to liver damage.

\section{Modulation of microbial composition/function to prevent graft fibrosis}

The gut microbiome is to some extent a modifiable entity (Caporaso et al. 2011). During early life, children may be more sensitive to changing the composition of the microbiome by diet or other factors, due to the still underdeveloped microbial colonization in pediatric gut (Derrien et al. 2019). Understanding the role of the gut microbiome in the development of graft fibrosis post-LT can open new avenues for the development of microbiome-based biomarkers for early diagnosis and microbiome-targeting approaches for disease prevention. Such approaches include dietary intervention, administration of probiotics/prebiotics, and even fecal microbiota transplantation.

\section{Diet recommendation and nutrition advice post LT}

Nutritional support is very crucial in children undergoing LT. Infants with end-stage liver diseases often exhibit growth failure due to impaired absorption of nutrition (Yang et al. 2017). LT outcomes improve if malnutrition can be resolved before surgery and a good nutritional status should 


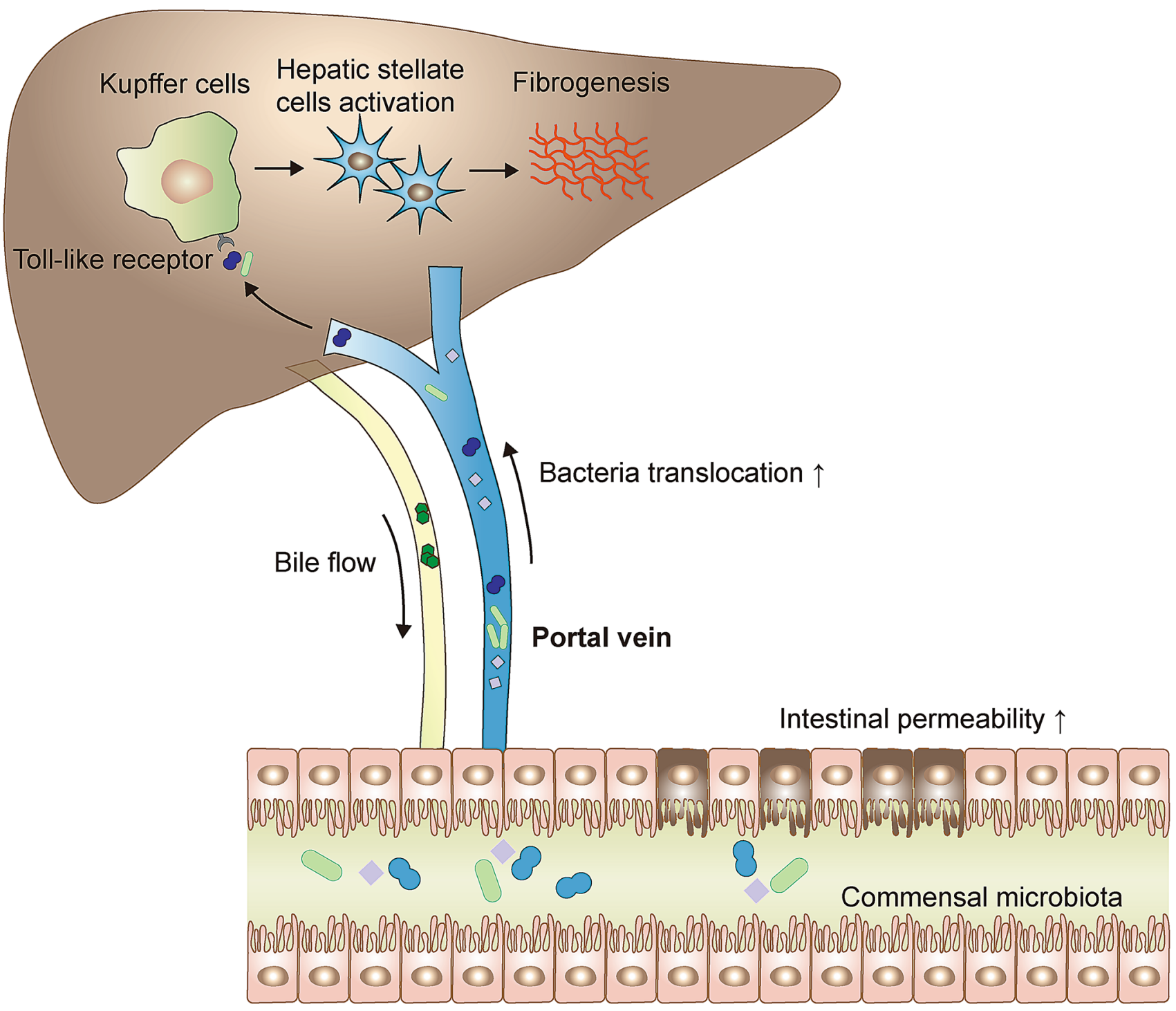

Altered microbial

Intestinal epithelial cells composition/function

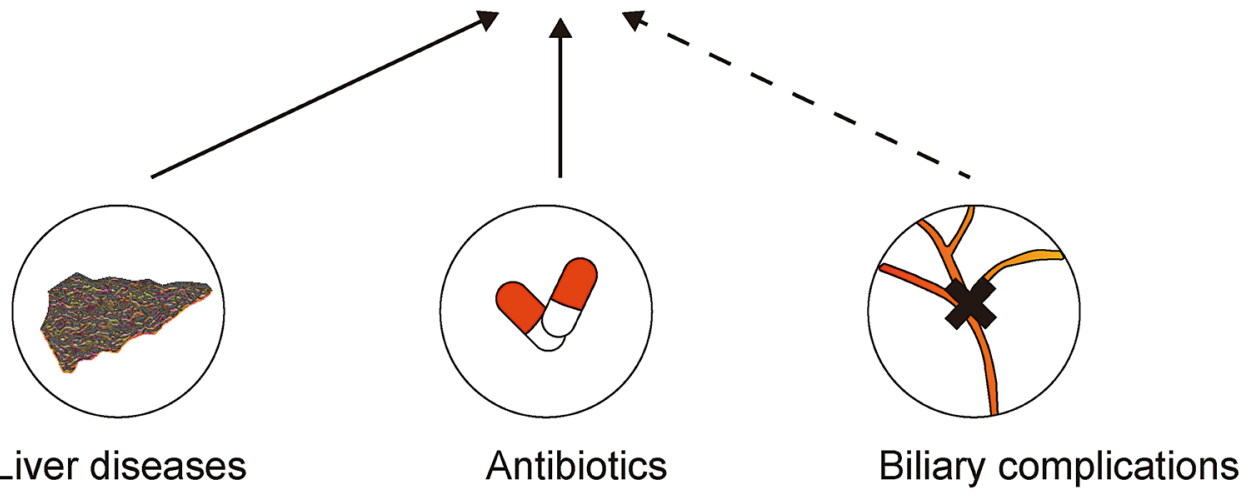

Fig. 2 Translocation of PAMPs due to higher intestinal permeability. Alteration of the intestinal microbiome, caused by liver diseases, administration of antibiotics or potential post-LT complications, is hypothesized to contribute to the graft fibrogenesis. Thus, the altered microbial composition/function leads to increased intestinal permeability and translocation of bacteria along with PAMPs to liver via the portal vein. Translocated PAMPs activate TLRs on hepatic Kupffer cells to induce the proinflammatory pathways, further resulting in the activation of HSCs. HSCs produce the ECM and initiate the liver fibrogenesis. ECM, extracellular matrix, $H S C$ hepatic stellate cell, $P A M P$ pathogen-associated molecular pattern, TLR toll-like receptor 


\section{A Hypothesis Potential role of gut microbiome on the development of liver graft fibrosis}

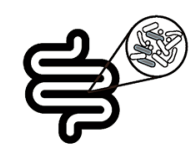

Altered microbial composition/function

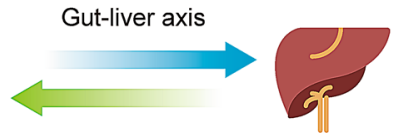

Liver graft fibrosis

\section{B Objective 1 To identify the microbial signature of graft fibrosis post LT.}

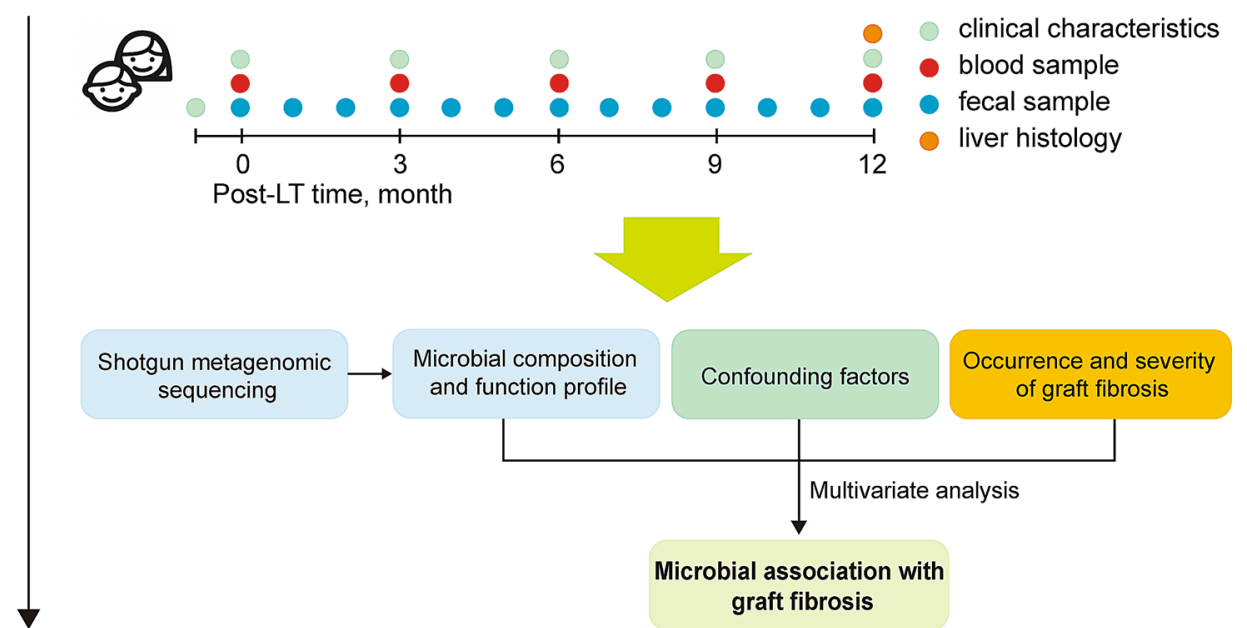

Objective 2 To explore the mechanisms of altered microbial composition/function contributing to graft fibrosis.

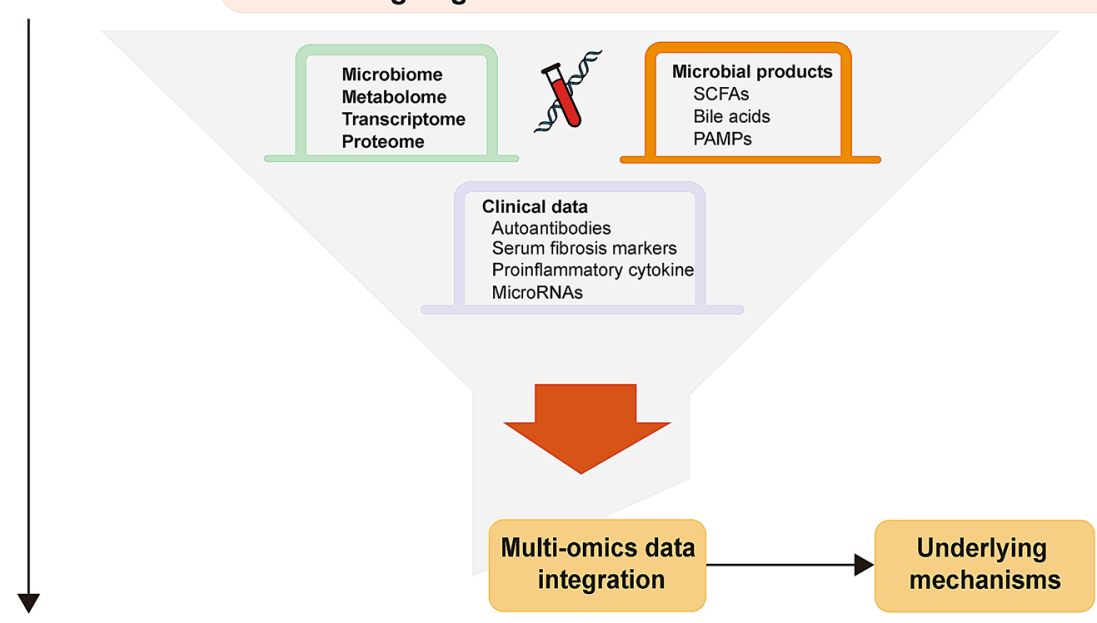

\section{Objective 3 To establish the causal role of the gut microbiome in graft fibrosis.}

Animal experiment

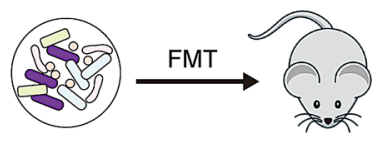

Microbiome manipulation in gnotobiotic mice
Microfluidic organ-on-a-chip technology

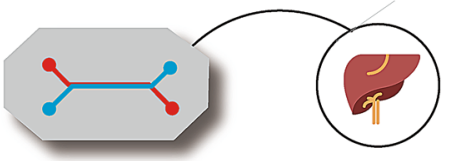

A microfluidic chip with microenvironment for hepatocytes 
4Fig. 3 Experimental framework to understand the role of microbial composition/function on the development of graft fibrosis post LT. a Hypothesis that altered gut microbial composition/function contributes to the development of graft fibrosis in pediatric LT; b Experimental framework containing three objectives to systematically evaluate various aspects of the hypothesized role of the gut microbiome on graft fibrosis after pediatric LT. FMT fecal microbiota transplant, $L T$ liver transplantation, PAMP pathogen-associated molecular pattern; $S C F A$ short-chain fatty acid

be maintained post-LT (Yang et al. 2017). In addition, supplementing fiber and probiotics to LT recipients decreased postoperative infections (Rayes et al. 2002). The impact of nutrition on fibrosis could (partly) be mediated through affecting the microbiome composition or function. Dependent on the age of children, fibers (especially oligosaccharides) are important sources of SCFAs and promote the growth of beneficial bacteria. The American Health Foundation recommends that children over 2 years old should take as daily amount of fiber their weight in years +5 to $+10 \mathrm{~g} / \mathrm{d}$ (Catzola and Vajro 2017). In general, supplementing fiber-containing diet post-LT might improve the gut health in infants. It is tempting to speculate that this could also prevent or mitigate graft fibrosis.

\section{Probiotics and prebiotics}

Probiotics refer to living bacteria that can benefit the health of the host, such as Lactobacillus and Bifidobacterium. Prebiotics are compounds in diet that induce the growth or activity of beneficial microorganisms. The beneficial role of probiotics and prebiotics in liver diseases has been documented in animal and human studies (Dhiman et al. 2014; Liu et al. 2017; Liu et al. 2019; Shi et al. 2017; Vajro et al. 2011). In murine models of liver fibrosis, administration of prebiotics reduced fibrosis and inflammation by reversing gut dysbiosis, decreasing production of inflammatory cytokines and downregulating expression of fibrogenic genes (Liu et al. 2017; Shi et al. 2017). Lactobacillus rhamnosus $G G$, a specific probiotic strain, prevents bile acid associated liver injury and fibrosis in mice (Liu et al. 2019). In human studies, probiotic supplementation also showed a beneficial effect. Corresponding to animal studies, probiotic treatment with Lactobacillus rhamnosus $G G$ in obese children (Vajro et al. 2011) revealed a significant decrease in alanine aminotransferase, irrespective of changes in BMI (body-mass index). In another randomized controlled study, children receiving VSL\#3 (a mixture of 8 probiotic strains) once daily for 4 months showed significant improvement in fatty liver disease severity, and a substantial reduction in BMI (Alisi et al. 2014). In transplant-related studies, administration of probiotics and prebiotics has beneficially impacted the liver graft in the short term (Jorgenson et al. 2018; Rayes et al. 2002). Pre-LT probiotic/prebiotic use reduced the postoperative infection rate as well as the length of hospitalization and of antibiotic use, based on a metaanalysis of four controlled studies (Sawas et al. 2015). Early biochemical tests of graft function improved although the long-term outcome appeared not different (Grat et al. 2017). Administration of probiotics in mouse LT model helped alleviate the acute rejection after surgery by improving the immune parameters, such as Treg cells (Xie et al. 2014). Probiotic/prebiotic administration warrants consideration as a therapeutic tool to treat gut dysbiosis with minimal side effects, and to reconstruct a healthy microbiome community, possibly alleviating liver injury and fibrosis.

\section{Fecal microbiome transplant (FMT)}

FMT is emerging as a powerful therapeutic approach for the treatment of $C$. difficile infection (Smits et al. 2016), as well as in patients with solid organ transplants (Cheng et al. 2019b; Kelly et al. 2014; Lin et al. 2018a; Shogbesan et al. 2018). LT recipients are more susceptible to $C$. difficile due to immunosuppression therapy, antibiotic treatment, and prolonged hospitalizations (Lin et al. 2018b). The efficacy and safety of FMT treatment have been proven in several LT cases (Lin et al. 2018b; Schneider et al. 2018). Notably, a recent multicenter study suggested repeated FMT with/without antibiotics therapy in LT recipients would improve the cure rate comparable to immunocompetent patients (Cheng et al. 2019a). Moreover, FMT has also been implemented for the treatment of metabolic disorders, like type 2 diabetes (Vrieze et al. 2012), NAFLD (Yuan et al. 2019), and decompensated cirrhosis (Bajaj et al. 2018b). This is based on the evidence that the restoration of the gut microbiome via FMT can impact on host's metabolism. In a phase 1 clinical trial, decompensated cirrhosis patients received 5 days of broad-spectrum antibiotics followed by FMT from a donor enriched in Lachnospiraceae and Ruminococcaceae (Bajaj et al. 2018b). In 15 days, FMT has restored the antibiotic-associated disruption of microbiota composition and improved fecal SCFA and BA profile. Thus we postulate that the simultaneous or consecutive transplantation of a healthy liver and healthy gut microbiome in patients with end-stage liver disease can reduce the risk of infection and help reestablish the healthy gut-liver axis, thereby increasing the prognosis rate of the liver graft.

\section{Experimental framework to study the microbial role in fibrosis}

As indicated above, the alteration of gut microbiome composition/function can be an important determinant in graft fibrosis after pediatric LT (Fig. 3a). Despite the high potential of microbiota-modulating approaches in preventing or mitigating graft fibrosis post LT, the supporting observations 
obtained so far have all been indirect. To date, there is no study evaluating the role of gut microbiota in the development of graft fibrosis in pediatric LT. To assess the hypothesis in a targeted study and, if positive, move towards clinical applications, we propose an experimental framework that contains three specific objectives to systematically determine various aspects of the intestinal microbiota on graft fibrosis (Fig. 3b).

\section{Objective 1: a longitudinal human study in pediatric liver transplant patients to identify the microbial signature of graft fibrosis post LT}

The prevalence of graft fibrosis is $\sim 50 \%$ at 1 year after pediatric LT. To identify an early microbial signature of graft fibrosis, it is essential to have a longitudinal study up to at least 1 year after pediatric LT, including a protocol liver biopsy for detailed analysis of liver histology and graft fibrosis. Detailed patient's characteristics should be recorded before and after LT, such as age, gender, weight, diet, and drug usage. Blood samples can be collected at baseline, as well as every 3 months after LT, following a regular standardized protocol. Fecal samples can be collected more frequently, for instance at baseline and monthly after LT. There are two commonly used sequencing technologies to determine the gut microbial composition: $16 \mathrm{~s}$ rRNA sequencing and shotgun metagenomic sequencing. $16 \mathrm{~s}$ rRNA sequencing is also known as amplicon sequencing, in which a specific, variable region of $16 \mathrm{~s}$ rRNA gene (e.g., V1, V3 or $\mathrm{V} 4$ region) is amplified and then subjected to sequencing (Weinstock 2012). The shotgun metagenomic sequencing refers to whole genome-wide sequencing, while bacterial genomes are fragmented to small species for sequencing. The use of $16 \mathrm{~s}$ rRNA sequencing has been approved to be an efficient and cost-effective strategy for microbial profiling. However, metagenomics sequencing clearly has several advantages over $16 \mathrm{~s}$ rRNA sequencing (Malla et al. 2019; Tessler et al. 2017). Firstly, 16 s rRNA sequencing can only identify bacteria, generally up to the genus level. Metagenomic sequencing can identify all kinds of microorganisms at the species and even strain level, including bacteria, viruses, and fungi. Secondly, metagenomic sequencing identifies the abundance of bacterial genes that can directly refer to bacterial functionality, which information cannot be directly obtained by $16 \mathrm{~s}$ rRNA sequencing. Thirdly, metagenomics sequencing offers us an opportunity to identify unknown organisms via de novo assembling, which is impossible for $16 \mathrm{~s}$ rRNA sequencing. After metagenomic sequencing, various analysis tools, such as MetaPhlan and Humman2 (Franzosa et al. 2018; Segata et al. 2012), can be employed to identify the abundance of different bacterial species and their metabolic pathways. This approach allows us to characterize the diversity of the microbial community. In such a way, the change of microbial compositions and their functional profile after LT can be monitored and it can be assessed to what extent the gut microbiome at baseline and its changes after transplantation can be associated with the occurrence and severity of graft fibrosis. Notably, both the development of graft fibrosis and the gut microbiome are complex. The possible confounding effects from other factors, such as diet and drug usage, need to be taken into account in assessing the microbial association with the development of graft fibrosis using multivariate analysis.

\section{Objective 2: multi-omics integration to gain insight into the underlying mechanisms}

Once the microbial association with graft fibrosis is established in objective 1, the next logical step is to understand through which mechanistic routes the (persistent or emerging) altered microbial composition/function contributes to the development of graft fibrosis. Multi-omics combined with systemic biology approaches have been considered to be a powerful approach to decipher the underlying molecular basis (Hasin et al. 2017). Firstly, it is important to identify microbial products that can impact the host's immunity and metabolism, such as SCFAs, bile acids and PAMPs that were discussed above. It needs to be assessed whether graft fibrosis-associated microbial alterations are also associated with abnormal levels of these microbial products. Secondly, it then needs to be understood how these microbial products can affect the host, thereby contributing to the development of graft fibrosis. This requires deep omics profiling in LT patients, including transcriptomics, proteomics, and metabolomics, in addition to the profiling of previously established fibrosis risk factors and biomarkers, such as autoantibodies (Venturi et al. 2014), serum fibrosis markers (e.g., hyaluronic acid, alpha-smooth muscle actin, tissue inhibitor of matrix metalloproteinase) (Varma et al. 2017; Voutilainen et al. 2017), proinflammatory cytokines and microRNAs (Kelly et al. 2016). A historical approach is needed to identify all downstream molecular factors that can be affected by the gut microbiome, followed by pathway and network analysis to converge these factors into molecular pathways. Unfortunately, multi-omics integration often encounters technical challenges related to statistical methods and power issues (Hasin et al. 2017; Misra et al. 2018). Such challenges are even more severe as cross-kingdom omics integration has been recently proposed to understand host-microbe interactions (Chen et al. 2018), in which host omics data are integrated with metagenome-based omics data, namely meta-transcriptomics, meta-proteomics, and meta-metabolomics. Such an analysis would definitely need a huge sample size to ensure satisfying analysis power. This highlights 
the importance of biobanks and large human cohorts in the big data era.

\section{Objective 3: moving from associations to causality and clinical applications}

The last step is to address the postulated causal role of the gut microbiome in graft fibrosis. Mouse models can be a useful tool to investigate causality, by observing the phenotypic consequences of microbiome manipulation in gnotobiotic mice (Kubelkova et al. 2016). Several experimental mouse models have been developed to study liver fibrosis (Yanguas et al. 2016). However, when we use mouse models to understand host-microbe interactions in humans, the differences between human and mouse need to be considered. For instance, bile acids profiles are remarkably different between human and mouse, due to the murine-specific cyp $2 c 70$ gene that produces $\alpha$-muricholic acid (MCA) (de Boer et al. 2018). Recently, a cyp2c70 knock-out mouse model has been developed, with a humanized bile acid profile (de Boer et al. 2020). Such a model, particularly when germ-free, would be appropriate to investigate the role of the gut microbiome in liver fibrosis via the mechanistic route of bile acids. Nevertheless, it is well known that mouse models frequently fall short in predicting human physiology. In recent years, microfluidic organ-on-a-chip (OoC) technology has been emerging as an innovative, animal alternative method to study human physiology and disease mechanisms (Sun et al. 2019). This technology allows to engineer a microfluidic chip and to create a microenvironment for human cells so that they can behave as they do inside a human body, thereby recapitulating the physiology of a specific organ. Liver-on-a-chip has been employed to identify human-specific drug toxicity (Jang et al. 2019). Another major advantage of the OoC technology is the possibility to employ human genetics into disease etiology, by combining $\mathrm{OoC}$ with human pluripotent induced stem cell technology (Rowe and Daley 2019; Workman et al. 2018). With the advance in bacterial culture technique (Lagier et al. 2018), these cutting-edge technologies offer us an opportunity to understand the host-microbe interactions in human disease, including graft fibrosis. Such knowledge is badly needed for developing microbiome-targeting approaches to prevent or at least mitigate the development of graft fibrosis and improve the wellbeing of patients.

\section{Conclusions}

Pediatric LT is a life-saving option for children with endstage liver diseases. However, about of $50 \%$ of patients develop graft fibrosis within 1 year after transplantation. Enormous efforts have been made to find ways to prevent or mitigate liver graft fibrosis, unfortunately, so far without much success. In recent years, accumulating observations suggest that the altered microbial composition/function is an important player in liver diseases and possibly is related to graft fibrosis after pediatric LT. Here we provide a prospective view on the role of the gut microbiome in graft fibrogenesis after pediatric LT and highlight the potential of microbiome-based approaches for early diagnosis, prevention and treatment. To realize this potential, collective efforts from clinical doctors, bioinformaticians, molecular biologists and microbiologists are required to test the hypothesis and, if positive, to obtain direct evidence and to uncover the underlying mechanisms.

Acknowledgements Q.T. is supported to by a joint fellowship from the University Medical Center Groningen and China Scholarship Council (201906230339). J.F. is supported by the Netherlands Heart Foundation (IN-CONTROL CVON Grant 2018-27), the Netherlands Organization for Scientific Research (NWO) (VIDI 864.13.013 and Gravitation grant Netherlands Organ-on-Chip Initiative 024.003.001). H.J.V. is supported by the European Society of Pediatric Gastroenterology, Hepatology and Nutrition (Network grant), the University Medical Center of Groningen (MD PhD scholarships), the C\&W de Boer Stichting, and by unrestricted research grants (Albireo, Mirum).

\section{Compliance with ethical standards}

Conflicts of interest The authors declare no conflict of interest.

Open Access This article is licensed under a Creative Commons Attribution 4.0 International License, which permits use, sharing, adaptation, distribution and reproduction in any medium or format, as long as you give appropriate credit to the original author(s) and the source, provide a link to the Creative Commons licence, and indicate if changes were made. The images or other third party material in this article are included in the article's Creative Commons licence, unless indicated otherwise in a credit line to the material. If material is not included in the article's Creative Commons licence and your intended use is not permitted by statutory regulation or exceeds the permitted use, you will need to obtain permission directly from the copyright holder. To view a copy of this licence, visit http://creativecommons.org/licenses/by/4.0/.

\section{References}

Albillos A, de Gottardi A, Rescigno M (2020) The gut-liver axis in liver disease: pathophysiological basis for therapy. J Hepatol 72:558-577. https://doi.org/10.1016/j.jhep.2019.10.003

Alisi A, Bedogni G, Baviera G, Giorgio V, Porro E, Paris C, Giammaria P, Reali L, Anania F, Nobili V (2014) Randomised clinical trial: the beneficial effects of VSL\#3 in obese children with non-alcoholic steatohepatitis. Aliment Pharmacol Ther 39:1276-1285. https://doi.org/10.1111/apt.12758

Annavajhala MK, Gomez-Simmonds A, Macesic N, Sullivan SB, Kress A, Khan SD, Giddins MJ, Stump S, Kim GI, Narain R, Verna EC, Uhlemann AC (2019) Colonizing multidrug-resistant bacteria and the longitudinal evolution of the intestinal microbiome after liver transplantation. Nat Commun 10:4715. https://doi. org/10.1038/s41467-019-12633-4 
Ardalan M, Vahed SZ (2017) Gut microbiota and renal transplant outcome. Biomed Pharmacother 90:229-236. https://doi. org/10.1016/j.biopha.2017.02.114

Arpaia N, Campbell C, Fan X, Dikiy S, van der Veeken J, deRoos P, Liu H, Cross JR, Pfeffer K, Coffer PJ, Rudensky AY (2013) Metabolites produced by commensal bacteria promote peripheral regulatory T-cell generation. Nature 504:451-455. https://doi. org/10.1038/nature 12726

Baas M, Gouw ASH, van den Heuvel MC, Hepkema BG, Peeters P, Verkade H, Scheenstra R (2017) Unique clinical conditions associated with different acinar regions of fibrosis in long-term surviving pediatric liver grafts. Pediatr Transpl. https://doi. org/10.1111/petr.12988

Bach Knudsen KE, Lærke HN, Hedemann MS, Nielsen TS, Ingerslev AK, Gundelund Nielsen DS, Theil PK, Purup S, Hald S, Schioldan AG, Marco ML, Gregersen S, Hermansen K (2018) Impact of diet-modulated butyrate production on intestinal barrier function and inflammation. Nutrients. https://doi.org/10.3390/nu101 01499

Bajaj JS (2019) Alcohol, liver disease and the gut microbiota. Nat Rev Gastroenterol Hepatol 16:235-246. https://doi.org/10.1038/ s41575-018-0099-1

Bajaj JS, Fagan A, Sikaroodi M, White MB, Sterling RK, Gilles H, Heuman D, Stravitz RT, Matherly SC, Siddiqui MS, Puri P, Sanyal AJ, Luketic V, John B, Fuchs M, Ahluwalia V, Gillevet PM (2017) Liver transplant modulates gut microbial dysbiosis and cognitive function in cirrhosis. Liver Transpl 23:907-914. https ://doi.org/10.1002/lt.24754

Bajaj JS, Kakiyama G, Cox IJ, Nittono H, Takei H, White M, Fagan A, Gavis EA, Heuman DM, Gilles HC, Hylemon P, TaylorRobinson SD, Legido-Quigley C, Kim M, Xu J, Williams R, Sikaroodi M, Pandak WM, Gillevet PM (2018a) Alterations in gut microbial function following liver transplant. Liver Transpl 24:752-761. https://doi.org/10.1002/lt.25046

Bajaj JS, Kakiyama G, Savidge T, Takei H, Kassam ZA, Fagan A, Gavis EA, Pandak WM, Nittono H, Hylemon PB, Boonma P, Haag A, Heuman DM, Fuchs M, John B, Sikaroodi M, Gillevet PM (2018b) Antibiotic-associated disruption of microbiota composition and function in cirrhosis is restored by fecal transplant. Hepatology 68:1549-1558. https://doi.org/10.1002/hep.30037

Bourdeaux C, Brunati A, Janssen M, de Magnee C, Otte JB, Sokal E, Reding R (2009) Liver retransplantation in children. A 21-year single-center experience. Transpl Int 22:416-422. https://doi. org/10.1111/j.1432-2277.2008.00807.x

Boursier J, Mueller O, Barret M, Machado M, Fizanne L, AraujoPerez F, Guy CD, Seed PC, Rawls JF, David LA, Hunault G, Oberti F, Cales P, Diehl AM (2016) The severity of nonalcoholic fatty liver disease is associated with gut dysbiosis and shift in the metabolic function of the gut microbiota. Hepatology 63:764-775. https://doi.org/10.1002/hep.28356

Caporaso JG, Lauber CL, Costello EK, Berg-Lyons D, Gonzalez A, Stombaugh J, Knights D, Gajer P, Ravel J, Fierer N, Gordon JI, Knight R (2011) Moving pictures of the human microbiome. Genome Biol 12:R50. https://doi.org/10.1186/ gb-2011-12-5-r50

Catzola A, Vajro P (2017) Management options for cholestatic liver disease in children. Expert Rev Gastroenterol Hepatol 11:10191030. https://doi.org/10.1080/17474124.2017.1359538

Chanpong A, Angkathunyakul N, Sornmayura P, Tanpowpong P, Lertudomphonwanit C, Panpikoon T, Treepongkaruna S (2019) Late allograft fibrosis in pediatric liver transplant recipients: assessed by histology and transient elastography. Pediatr Transpl 23:e13541. https://doi.org/10.1111/petr.13541

Chen Y, Yang F, Lu H, Wang B, Chen Y, Lei D, Wang Y, Zhu B, Li L (2011) Characterization of fecal microbial communities in patients with liver cirrhosis. Hepatology 54:562-572. https://doi. org/10.1002/hep. 24423

Chen L, Garmaeva S, Zhernakova A, Fu J, Wijmenga C (2018) A system biology perspective on environment-host-microbe interactions. Hum Mol Genet 27:R187-r194. https://doi.org/10.1093/ hmg/ddy 137

Chen D, Le TH, Shahidipour H, Read SA, Ahlenstiel G (2019) The role of gut-derived microbial antigens on liver fibrosis initiation and progression. Cells 8:1324. https://doi.org/10.3390/cells8111324

Cheng Y-W, Phelps E, Ganapini V, Khan N, Ouyang F, Xu H, Khanna S, Tariq R, Friedman-Moraco RJ, Woodworth MH, Dhere T, Kraft CS, Kao D, Smith J, Le L, El-Nachef N, Kaur N, Kowsika S, Ehrlich A, Smith M, Safdar N, Misch EA, Allegretti JR, Flynn A, Kassam Z, Sharfuddin A, Vuppalanchi R, Fischer M (2019a) Fecal microbiota transplantation for the treatment of recurrent and severe Clostridium difficile infection in solid organ transplant recipients: a multicenter experience. Am J Transpl 19:501-511. https://doi.org/10.1111/ajt.15058

Cheng YW, Phelps E, Ganapini V, Khan N, Ouyang F, Xu H, Khanna S, Tariq R, Friedman-Moraco RJ, Woodworth MH, Dhere T, Kraft CS, Kao D, Smith J, Le L, El-Nachef N, Kaur N, Kowsika S, Ehrlich A, Smith M, Safdar N, Misch EA, Allegretti JR, Flynn A, Kassam Z, Sharfuddin A, Vuppalanchi R, Fischer M (2019b) Fecal microbiota transplantation for the treatment of recurrent and severe Clostridium difficile infection in solid organ transplant recipients: a multicenter experience. Am J Transplant 19:501511. https://doi.org/10.1111/ajt.15058

Chenyang Wang QL, Li Jieshou (2018) Gut microbiota and its implications in small bowel transplantation. Front. Med. 12:239-248. https://doi.org/10.1007/s11684-018-0617-0

de Boer JF, Bloks VW, Verkade E, Heiner-Fokkema MR, Kuipers F (2018) New insights in the multiple roles of bile acids and their signaling pathways in metabolic control. Curr Opin Lipidol 29:194-202. https://doi.org/10.1097/mol.0000000000000508

de Boer JF, Verkade E, Mulder NL, de Vries HD, Huijkman N, Koehorst M, Boer T, Wolters JC, Bloks VW, van de Sluis B, Kuipers F (2020) A human-like bile acid pool induced by deletion of hepatic Cyp2c70 modulates effects of FXR activation in mice. J Lipid Res 61:291-305. https://doi.org/10.1194/jlr.RA119000243

De Minicis S, Rychlicki C, Agostinelli L, Saccomanno S, Candelaresi C, Trozzi L, Mingarelli E, Facinelli B, Magi G, Palmieri C, Marzioni M, Benedetti A, Svegliati-Baroni G (2014) Dysbiosis contributes to fibrogenesis in the course of chronic liver injury in mice. Hepatology 59:1738-1749. https://doi.org/10.1002/ hep. 26695

Derrien M, Alvarez AS, de Vos WM (2019) The gut microbiota in the first decade of life. Trends Microbiol 27:997-1010. https://doi. org/10.1016/j.tim.2019.08.001

Dhiman RK, Rana B, Agrawal S, Garg A, Chopra M, Thumburu KK, Khattri A, Malhotra S, Duseja A, Chawla YK (2014) Probiotic VSL\#3 reduces liver disease severity and hospitalization in patients with cirrhosis: a randomized, controlled trial. Gastroenterology 147:1327-1337. https://doi.org/10.1053/j.gastr o.2014.08.031 (e3)

Ding Y, Yanagi K, Cheng C, Alaniz RC, Lee K, Jayaraman A (2019) Interactions between gut microbiota and non-alcoholic liver disease: the role of microbiota-derived metabolites. Pharmacol Res 141:521-529. https://doi.org/10.1016/j.phrs.2019.01.029

Egawa H, Miyagawa-Hayashino A, Haga H, Teramukai S, Yoshizawa A, Ogawa K, Ogura Y, Okamoto S, Kaido T, Uemoto S (2012) Non-inflammatory centrilobular sinusoidal fibrosis in pediatric liver transplant recipients under tacrolimus withdrawal. Hepatol Res 42:895-903. https://doi.org/10.1111/j.1872034X.2012.01003.X

Evans HM, Kelly DA, McKiernan PJ, Hubscher S (2006) Progressive histological damage in liver allografts following pediatric 
liver transplantation. Hepatology 43:1109-1117. https://doi. org/10.1002/hep. 21152

Everard A, Belzer C, Geurts L, Ouwerkerk JP, Druart C, Bindels LB, Guiot Y, Derrien M, Muccioli GG, Delzenne NM, de Vos WM, Cani PD (2013) Cross-talk between Akkermansia muciniphila and intestinal epithelium controls diet-induced obesity. Proc Natl Acad Sci USA 110:9066-9071. https://doi.org/10.1073/ pnas. 1219451110

Feng S, Bucuvalas JC, Demetris AJ, Burrell BE, Spain KM, Kanaparthi S, Magee JC, Ikle D, Lesniak A, Lozano JJ, Alonso EM, Bray RA, Bridges NE, Doo E, Gebel HM, Gupta NA, Himes RW, Jackson AM, Lobritto SJ, Mazariegos GV, Ng VL, Rand EB, Sherker AH, Sundaram S, Turmelle YP, Sanchez-Fueyo A (2018) Evidence of chronic allograft injury in liver biopsies from longterm pediatric recipients of liver transplants. Gastroenterology 155:1838-1851. https://doi.org/10.1053/j.gastro.2018.08.023 (e7)

Fischler B, Baumann U, D’Agostino D, D'Antiga L, Dezsofi A, Debray D, Durmaz O, Evans H, Frauca E, Hadzic N, Jahnel J, Loveland J, McLin V, Ng VL, Nobili V, Pawlowska J, Sharif K, Smets F, Verkade HJ, Hsu E, Horslen S, Bucuvalas J (2019) Similarities and differences in allocation policies for pediatric liver transplantation across the world. J Pediatr Gastroenterol Nutr 68:700-705. https://doi.org/10.1097/mpg.0000000000002283

Fouts DE, Torralba M, Nelson KE, Brenner DA, Schnabl B (2012) Bacterial translocation and changes in the intestinal microbiome in mouse models of liver disease. J Hepatol 56:1283-1292. https ://doi.org/10.1016/j.jhep.2012.01.019

Franzosa EA, McIver LJ, Rahnavard G, Thompson LR, Schirmer M, Weingart G, Lipson KS, Knight R, Caporaso JG, Segata N, Huttenhower C (2018) Species-level functional profiling of metagenomes and metatranscriptomes. Nat Methods 15:962-968. https ://doi.org/10.1038/s41592-018-0176-y

Gabele E, Muhlbauer M, Dorn C, Weiss TS, Froh M, Schnabl B, Wiest R, Scholmerich J, Obermeier F, Hellerbrand C (2008) Role of TLR9 in hepatic stellate cells and experimental liver fibrosis. Biochem Biophys Res Commun 376:271-276. https://doi. org/10.1016/j.bbrc.2008.08.096

Gadaleta RM, van Erpecum KJ, Oldenburg B, Willemsen EC, Renooij W, Murzilli S, Klomp LW, Siersema PD, Schipper ME, Danese S, Penna G, Laverny G, Adorini L, Moschetta A, van Mil SW (2011) Farnesoid X receptor activation inhibits inflammation and preserves the intestinal barrier in inflammatory bowel disease. Gut 60:463-472. https://doi.org/10.1136/gut.2010.212159

Grander C, Adolph TE, Wieser V, Lowe P, Wrzosek L, Gyongyosi B, Ward DV, Grabherr F, Gerner RR, Pfister A, Enrich B, Ciocan D, Macheiner S, Mayr L, Drach M, Moser P, Moschen AR, Perlemuter G, Szabo G, Cassard AM, Tilg H (2018) Recovery of ethanol-induced Akkermansia muciniphila depletion ameliorates alcoholic liver disease. Gut 67:891-901. https://doi. org/10.1136/gutjnl-2016-313432

Grat M, Wronka KM, Lewandowski Z, Grat K, Krasnodebski M, Stypulkowski J, Holowko W, Masior L, Kosinska I, Wasilewicz M, Raszeja-Wyszomirska J, Rejowski S, Bik E, Patkowski W, Krawczyk M (2017) Effects of continuous use of probiotics before liver transplantation: a randomized, double-blind, placebo-controlled trial. Clin Nutr 36:1530-1539. https://doi. org/10.1016/j.clnu.2017.04.021

Guo C, Li Y, Wang P, Li Y, Qiu C, Li M, Wang D, Zhao R, Li D, Wang Y, Li S, Dai W, Zhang L (2018) Alterations of gut microbiota in cholestatic infants and their correlation with hepatic function. Front Microbiol 9:2682. https://doi.org/10.3389/ fmicb.2018.02682

Hartmann P, Haimerl M, Mazagova M, Brenner DA, Schnabl B (2012) Toll-like receptor 2-mediated intestinal injury and enteric tumor necrosis factor receptor I contribute to liver fibrosis in mice. Gastroenterology 143:1330-1340. https:// doi.org/10.1053/j.gastro.2012.07.099 (e1)

Hasin Y, Seldin M, Lusis A (2017) Multi-omics approaches to disease. Genome Biol 18:83. https://doi.org/10.1186/s1305 9-017-1215-1

Hassoun Z, Shah V, Lohse CM, Pankratz VS, Petrovic LM (2004) Centrilobular necrosis after orthotopic liver transplantation: association with acute cellular rejection and impact on outcome. Liver Transpl 10:480-487. https://doi.org/10.1002/1t.20122

Jackson AM, Kanaparthi S, Burrell BE, Lucas DP, Vega RM, Demetris AJ, Feng S (2020) IgG4 donor-specific HLA antibody profile is associated with subclinical rejection in stable pediatric liver recipients. Am J Transplant 20:513-524. https://doi.org/10.1111/ ajt. 15621

Jang KJ, Otieno MA, Ronxhi J, Lim HK, Ewart L, Kodella KR, Petropolis DB, Kulkarni G, Rubins JE, Conegliano D, Nawroth J, Simic D, Lam W, Singer M, Barale E, Singh B, Sonee M, Streeter AJ, Manthey C, Jones B, Srivastava A, Andersson LC, Williams D, Park H, Barrile R, Sliz J, Herland A, Haney S, Karalis K, Ingber DE, Hamilton GA (2019) Reproducing human and cross-species drug toxicities using a Liver-Chip. Sci Transl Med. https://doi. org/10.1126/scitranslmed.aax5516

Jorgenson MR, Descourouez JL, Siodlak M, Tjugum S, Rice JP, Fernandez LA (2018) Efficacy and safety of probiotics and synbiotics in liver transplantation. Pharmacotherapy. https://doi. org/10.1002/phar.2130

Kato K, Nagao M, Miyamoto K, Oka K, Takahashi M, Yamamoto M, Matsumura Y, Kaido T, Uemoto S, Ichiyama S (2017) Longitudinal analysis of the intestinal microbiota in liver transplantation. Transpl Direct 3:e144. https://doi.org/10.1097/TXD.0000000000 000661

Kelly CR, Ihunnah C, Fischer M, Khoruts A, Surawicz C, Afzali A, Aroniadis O, Barto A, Borody T, Giovanelli A, Gordon S, Gluck M, Hohmann EL, Kao D, Kao JY, McQuillen DP, Mellow M, Rank KM, Rao K, Ray A, Schwartz MA, Singh N, Stollman N, Suskind DL, Vindigni SM, Youngster I, Brandt L (2014) Fecal microbiota transplant for treatment of Clostridium difficile infection in immunocompromised patients. Am J Gastroenterol 109:1065-1071. https://doi.org/10.1038/ajg.2014.133

Kelly D, Verkade HJ, Rajanayagam J, McKiernan P, Mazariegos G, Hubscher S (2016) Late graft hepatitis and fibrosis in pediatric liver allograft recipients: current concepts and future developments. Liver Transpl 22:1593-1602. https://doi.org/10.1002/ 1t. 24616

Kubelkova K, Benuchova M, Kozakova H, Sinkora M, Krocova Z, Pejchal J, Macela A (2016) Gnotobiotic mouse model's contribution to understanding host-pathogen interactions. Cell Mol Life Sci 73:3961-3969. https://doi.org/10.1007/s00018-016-2341-8

Lagier J-C, Dubourg G, Million M, Cadoret F, Bilen M, Fenollar F, Levasseur A, Rolain J-M, Fournier P-E, Raoult D (2018) Culturing the human microbiota and culturomics. Nat Rev Microbiol 16:540-550. https://doi.org/10.1038/s41579-018-0041-0

Lee M (2017) Antibody-mediated rejection after liver transplant. Gastroenterol Clin North Am 46:297-309. https://doi.org/10.1016/j. gtc.2017.01.005

Li M, Cai S-Y, Boyer JL (2017) Mechanisms of bile acid mediated inflammation in the liver. Mol Aspects Med 56:45-53. https:// doi.org/10.1016/j.mam.2017.06.001

Lin SC, Alonso CD, Moss AC (2018) Fecal microbiota transplantation for recurrent Clostridium difficile infection in patients with solid organ transplants: an institutional experience and review of the literature. Transpl Infect Dis 20:e12967. https://doi.org/10.1111/ tid. 12967

Liu J, Fu Y, Zhang H, Wang J, Zhu J, Wang Y, Guo Y, Wang G, Xu T, Chu M, Wang F (2017) The hepatoprotective effect of the probiotic Clostridium butyricum against carbon tetrachloride-induced 
acute liver damage in mice. Food Funct 8:4042-4052. https://doi. org/10.1039/c7fo00355b

Liu Y, Chen K, Li F, Gu Z, Liu Q, He L, Shao T, Song Q, Zhu F, Zhang L, Jiang M, Zhou Y, Barve S, Zhang X, McClain CJ, Feng W (2019) Probiotic LGG prevents liver fibrosis through inhibiting hepatic bile acid synthesis and enhancing bile acid excretion in mice. Hepatology. https://doi.org/10.1002/hep.30975

Llopis M, Cassard AM, Wrzosek L, Boschat L, Bruneau A, Ferrere G, Puchois V, Martin JC, Lepage P, Le Roy T, Lefevre L, Langelier B, Cailleux F, Gonzalez-Castro AM, Rabot S, Gaudin F, Agostini H, Prevot S, Berrebi D, Ciocan D, Jousse C, Naveau S, Gerard $P$, Perlemuter G (2016) Intestinal microbiota contributes to individual susceptibility to alcoholic liver disease. Gut 65:830-839. https://doi.org/10.1136/gutjnl-2015-310585

Lu H, He J, Wu Z, Xu W, Zhang H, Ye P, Yang J, Zhen S, Li L (2013) Assessment of microbiome variation during the perioperative period in liver transplant patients: a retrospective analysis. Microb Ecol 65:781-791. https://doi.org/10.1007/s0024 8-013-0211-6

Lu H-F, Ren Z-G, Li A, Zhang H, Xu S-Y, Jiang J-W, Zhou L, Ling Q, Wang B-H, Cui G-Y, Chen X-H, Zheng S-S, Li L-J (2019) Fecal microbiome data distinguish liver recipients with normal and abnormal liver function from healthy controls. Front Microbiol 10:1518. https://doi.org/10.3389/fmicb.2019.01518

Lynch SV, Pedersen O (2016) The Human Intestinal Microbiome in Health and disease. N Engl J Med 375:2369-2379. https://doi. org/10.1056/NEJMra1600266

Madsen BS, Trebicka J, Thiele M, Israelsen M, Arumugan M, Havelund T, Krag A (2018) Antifibrotic and molecular aspects of rifaximin in alcoholic liver disease: study protocol for a randomized controlled trial. Trials 19:143. https://doi.org/10.1186/ s13063-018-2523-9

Mahana D, Trent CM, Kurtz ZD, Bokulich NA, Battaglia T, Chung J, Muller CL, Li H, Bonneau RA, Blaser MJ (2016) Antibiotic perturbation of the murine gut microbiome enhances the adiposity, insulin resistance, and liver disease associated with high-fat diet. Genome Med 8:48. https://doi.org/10.1186/s13073-016-0297-9

Malla MA, Dubey A, Kumar A, Yadav S, Hashem A, Abd Allah EF (2019) Exploring the human microbiome: the potential future role of next-generation sequencing in disease diagnosis and treatment. Front Immunol 9:2868. https://doi.org/10.3389/fimmu .2018 .02868

Mazagova M, Wang L, Anfora AT, Wissmueller M, Lesley SA, Miyamoto Y, Eckmann L, Dhungana S, Pathmasiri W, Sumner S, Westwater C, Brenner DA, Schnabl B (2015) Commensal microbiota is hepatoprotective and prevents liver fibrosis in mice. Faseb j 29:1043-1055. https://doi.org/10.1096/fj.14-259515

Mihm S (2018) Danger-associated molecular patterns (DAMPs): molecular triggers for sterile inflammation in the liver. Int J Mol Sci. https://doi.org/10.3390/ijms19103104

Misra BB, Langefeld CD, Olivier M, Cox LA (2018) Integrated omics: tools, advances, and future approaches. J Mol Endocrinol. https ://doi.org/10.1530/jme-18-0055

Miyagawa-Hayashino A, Yoshizawa A, Uchida Y, Egawa H, Yurugi K, Masuda S, Minamiguchi S, Maekawa T, Uemoto S, Haga H (2012) Progressive graft fibrosis and donor-specific human leukocyte antigen antibodies in pediatric late liver allografts. Liver Transpl 18:1333-1342. https://doi.org/10.1002/lt.23534

Mörkl S, Lackner S, Meinitzer A, Mangge H, Lehofer M, Halwachs B, Gorkiewicz G, Kashofer K, Painold A, Holl AK, Bengesser SA, Müller W, Holzer P, Holasek SJ (2018) Gut microbiota, dietary intakes and intestinal permeability reflected by serum zonulin in women. Eur J Nutr 57:2985-2997. https://doi.org/10.1007/ s00394-018-1784-0
Müller M, Hernández MAG, Goossens GH, Reijnders D, Holst JJ, Jocken JWE, van Eijk H, Canfora EE, Blaak EE (2019) Circulating but not faecal short-chain fatty acids are related to insulin sensitivity, lipolysis and GLP-1 concentrations in humans. Sci Rep 9:12515. https://doi.org/10.1038/s41598-019-48775-0

Okumura R, Takeda K (2018) Maintenance of intestinal homeostasis by mucosal barriers. Inflamm Regen 38:5. https://doi.org/10.1186/ s41232-018-0063-z

Parada Venegas D, De la Fuente MK, Landskron G, González MJ, Quera R, Dijkstra G, Harmsen HJM, Faber KN, Hermoso MA (2019) Short chain fatty acids (SCFAS)-mediated gut epithelial and immune regulation and its relevance for inflammatory bowel diseases. Front Immunol 10:277. https://doi.org/10.3389/fimmu .2019 .00277

Peled JU, Gomes ALC, Devlin SM, Littmann ER, Taur Y, Sung AD, Weber D, Hashimoto D, Slingerland AE, Slingerland JB, Maloy M, Clurman AG, Stein-Thoeringer CK, Markey KA, Docampo MD, Burgos da Silva M, Khan N, Gessner A, Messina JA, Romero K, Lew MV, Bush A, Bohannon L, Brereton DG, Fontana E, Amoretti LA, Wright RJ, Armijo GK, Shono Y, SanchezEscamilla M, Castillo Flores N, Alarcon Tomas A, Lin RJ, Yáñez San Segundo L, Shah GL, Cho C, Scordo M, Politikos I, Hayasaka K, Hasegawa Y, Gyurkocza B, Ponce DM, Barker JN, Perales MA, Giralt SA, Jenq RR, Teshima T, Chao NJ, Holler E, Xavier JB, Pamer EG, van den Brink MRM (2020) Microbiota as predictor of mortality in allogeneic hematopoietic-cell transplantation. N Engl J Med 382:822-834. https://doi.org/10.1056/ NEJMoa1900623

Ponziani FR, Gerardi V, Pecere S, D’Aversa F, Lopetuso L, Zocco MA, Pompili M, Gasbarrini A (2015) Effect of rifaximin on gut microbiota composition in advanced liver disease and its complications. World J Gastroenterol 21:12322-12333. https://doi. org/10.3748/wjg.v21.i43.12322

Rayes N, Seehofer D, Hansen S, Boucsein K, Müller AR, Serke S, Bengmark S, Neuhaus P (2002) Early enteral supply of lactobacillus and fiber versus selective bowel decontamination: a controlled trial in liver transplant recipients. Transplantation 74:123127. https://doi.org/10.1097/00007890-200207150-00021

Rhu J, Ha SY, Lee S, Kim JM, Choi GS, Joh JW, Lee SK (2020) Risk factors of silent allograft fibrosis 10 years post-pediatric liver transplantation. Sci Rep 10:1833. https://doi.org/10.1038/s4159 8-020-58714-Z

Rowe RG, Daley GQ (2019) Induced pluripotent stem cells in disease modelling and drug discovery. Nat Rev Genet 20:377-388. https ://doi.org/10.1038/s41576-019-0100-z

Sawas T, Al Halabi S, Hernaez R, Carey WD, Cho WK (2015) Patients Receiving prebiotics and probiotics before liver transplantation develop fewer infections than controls: a systematic review and meta-analysis. Clin Gastroenterol Hepatol 13:1567-1574. https:// doi.org/10.1016/j.cgh.2015.05.027 (e3; quiz e143-e144)

Sayin SI, Wahlström A, Felin J, Jäntti S, Marschall HU, Bamberg K, Angelin B, Hyötyläinen T, Orešič M, Bäckhed F (2013) Gut microbiota regulates bile acid metabolism by reducing the levels of tauro-beta-muricholic acid, a naturally occurring FXR antagonist. Cell Metab 17:225-235. https://doi.org/10.1016/j. cmet.2013.01.003

Scheenstra R, Peeters PMGJ, Verkade HJ, Gouw ASH (2009) Graft fibrosis after pediatric liver transplantation: ten years of follow-up. Hepatology (Baltimore, MD) 49:880-886. https://doi. org/10.1002/hep.22686

Schneider KM, Wirtz TH, Kroy D, Albers S, Neumann UP, Strowig T, Sellge G, Trautwein C (2018) Successful fecal microbiota transplantation in a patient with severe complicated clostridium difficile infection after liver transplantation. Case Rep Gastroenterol 12:76-84. https://doi.org/10.1159/000481937 
Schulthess J, Pandey S, Capitani M, Rue-Albrecht KC, Arnold I, Franchini F, Chomka A, Ilott NE, Johnston DGW, Pires E, McCullagh J, Sansom SN, Arancibia-Cárcamo CV, Uhlig HH, Powrie F (2019) The short chain fatty acid butyrate imprints an antimicrobial program in macrophages. Immunity 50:432-445. https:// doi.org/10.1016/j.immuni.2018.12.018 e7

Schumacher JD, Kong B, Wu J, Rizzolo D, Armstrong LE, Chow MD, Goedken M, Lee YH, Guo GL (2020) Direct and indirect effects of fibroblast growth factor (FGF) 15 and FGF19 on liver fibrosis development. Hepatology 71:670-685. https://doi.org/10.1002/ hep. 30810

Schwimmer JB, Johnson JS, Angeles JE, Behling C, Belt PH, Borecki I, Bross C, Durelle J, Goyal NP, Hamilton G, Holtz ML, Lavine JE, Mitreva M, Newton KP, Pan A, Simpson PM, Sirlin CB, Sodergren E, Tyagi R, Yates KP, Weinstock GM, Salzman NH (2019) Microbiome signatures associated with steatohepatitis and moderate to severe fibrosis in children with nonalcoholic fatty liver disease. Gastroenterology 157:1109-1122. https://doi. org/10.1053/j.gastro.2019.06.028

Segain JP, Raingeard de la Blétière D, Bourreille A, Leray V, Gervois $\mathrm{N}$, Rosales C, Ferrier L, Bonnet C, Blottière HM, Galmiche JP (2000) Butyrate inhibits inflammatory responses through NFkappaB inhibition: implications for Crohn's disease. Gut 47:397403. https://doi.org/10.1136/gut.47.3.397

Segata N, Waldron L, Ballarini A, Narasimhan V, Jousson O, Huttenhower C (2012) Metagenomic microbial community profiling using unique clade-specific marker genes. Nat Methods 9:811814. https://doi.org/10.1038/nmeth.2066

Seki E, Schnabl B (2012) Role of innate immunity and the microbiota in liver fibrosis: crosstalk between the liver and gut. J Physiol 590:447-458. https://doi.org/10.1113/jphysiol.2011.219691

Seki E, Tsutsui H, Nakano H, Tsuji NM, Hoshino K, Adachi O, Adachi K, Futatsugi S, Kuida K, Takeuchi O, Okamura H, Fujimoto J, Akira S, Nakanishi K (2001) Lipopolysaccharide-induced IL-18 secretion from murine kupffer cells independently of myeloid differentiation factor 88 that is critically involved in induction of production of IL-12 and IL-1 $\beta$. J Immunol 166:2651-2657. https://doi.org/10.4049/jimmunol.166.4.2651

Seki E, De Minicis S, Osterreicher CH, Kluwe J, Osawa Y, Brenner DA, Schwabe RF (2007) TLR4 enhances TGF-beta signaling and hepatic fibrosis. Nat Med 13:1324-1332. https://doi.org/10.1038/ nm1663

Sender R, Fuchs S, Milo R (2016) Are we really vastly outnumbered? revisiting the ratio of bacterial to host cells in humans. Cell 164:337-340. https://doi.org/10.1016/j.cell.2016.01.013

Shi D, Lv L, Fang D, Wu W, Hu C, Xu L, Chen Y, Guo J, Hu X, Li A, Guo F, Ye J, Li Y, Andayani D, Li L (2017) Administration of Lactobacillus salivarius LI01 or Pediococcus pentosaceus LI05 prevents $\mathrm{CCl}(4)$-induced liver cirrhosis by protecting the intestinal barrier in rats. Sci Rep 7:6927. https://doi.org/10.1038/s4159 8-017-07091-1

Shogbesan O, Poudel DR, Victor S, Jehangir A, Fadahunsi O, Shogbesan G, Donato A (2018) A systematic review of the efficacy and safety of fecal microbiota transplant for clostridium difficile infection in immunocompromised patients. Can J Gastroenterol Hepatol 2018:1394379. https://doi.org/10.1155/2018/1394379

Smith PM, Howitt MR, Panikov N, Michaud M, Gallini CA, BohloolyY M, Glickman JN, Garrett WS (2013) The microbial metabolites, short-chain fatty acids, regulate colonic $\mathrm{T}<\mathrm{sub}>\mathrm{reg}<1$ sub $>$ Cell homeostasis. Science 341:569-573. https://doi. org/10.1126/science.1241165

Smits WK, Lyras D, Lacy DB, Wilcox MH, Kuijper EJ (2016) Clostridium difficile infection. Nat Rev Dis Primers 2:16020. https://doi. org/10.1038/nrdp.2016.20
Sun L-Y, Yang Y-S, Qu W, Zhu Z-J, Wei L, Ye Z-S, Zhang J-R, Sun X-Y, Zeng Z-G (2017) Gut microbiota of liver transplantation recipients. Sci Rep 7:3762. https://doi.org/10.1038/s41598-01703476-4

Sun W, Luo Z, Lee J, Kim HJ, Lee K, Tebon P, Feng Y, Dokmeci MR, Sengupta S, Khademhosseini A (2019) Organ-on-a-chip for cancer and immune organs modeling. Adv Healthc Mater 8:e1801363. https://doi.org/10.1002/adhm.201801363

Sundaram SS, Melin-Aldana H, Neighbors K, Alonso EM (2006) Histologic characteristics of late cellular rejection, significance of centrilobular injury, and long-term outcome in pediatric liver transplant recipients. Liver Transpl 12:58-64. https://doi. org/10.1002/lt.20661

Tedesco D, Grakoui A (2018) Environmental peer pressure: CD4(+) T cell help in tolerance and transplantation. Liver Transpl 24:8997. https://doi.org/10.1002/lt.24873

Tessler M, Neumann JS, Afshinnekoo E, Pineda M, Hersch R, Velho LFM, Segovia BT, Lansac-Toha FA, Lemke M, DeSalle R, Mason CE, Brugler MR (2017) Large-scale differences in microbial biodiversity discovery between $16 \mathrm{~S}$ amplicon and shotgun sequencing. Sci Rep 7:6589. https://doi.org/10.1038/s41598-01706665-3

Tokodai K, Miyagi S, Nakanishi C, Hara Y, Nakanishi W, Miyazawa K, Shimizu K, Murakami K, Sasano H, Goto M, Unno M, Kamei T (2018) Association of post-transplant donor-specific HLA antibody with liver graft fibrosis during long-term follow-up after pediatric liver transplantation. Pediatric Transpl 22:e13169. https ://doi.org/10.1111/petr.13169

Tripathi A, Debelius J, Brenner DA, Karin M, Loomba R, Schnabl B, Knight R (2018) The gut-liver axis and the intersection with the microbiome. Nat Rev Gastroenterol Hepatol 15:397-411. https ://doi.org/10.1038/s41575-018-0011-z

Tulstrup MV, Christensen EG, Carvalho V, Linninge C, Ahrné S, Højberg O, Licht TR, Bahl MI (2015) Antibiotic treatment affects intestinal permeability and gut microbial composition in wistar rats dependent on antibiotic class. PLoS ONE 10:e144854. https ://doi.org/10.1371/journal.pone.0144854

Ueno T, Zenitani M, Yamanaka H, Tanaka N, Uehara S, Tazuke Y, Bessho K, Okuyama H (2016) Impact of donor-specific antibodies on graft fibrosis after pediatric living donor liver transplantation for biliary atresia. Transpl Proc 48:1095-1099. https://doi. org/10.1016/j.transproceed.2016.02.011

Usami M, Kishimoto K, Ohata A, Miyoshi M, Aoyama M, Fueda Y, Kotani J (2008) Butyrate and trichostatin A attenuate nuclear factor $\kappa \mathrm{B}$ activation and tumor necrosis factor $\alpha$ secretion and increase prostaglandin E2 secretion in human peripheral blood mononuclear cells. Nutr Res 28:321-328. https://doi. org/10.1016/j.nutres.2008.02.012

Vajro P, Mandato C, Licenziati MR, Franzese A, Vitale DF, Lenta S, Caropreso M, Vallone G, Meli R (2011) Effects of Lactobacillus rhamnosus strain GG in pediatric obesity-related liver disease. J Pediatr Gastroenterol Nutr 52:740-743. https://doi.org/10.1097/ MPG.0b013e31821f9b85

Valdes AM, Walter J, Segal E, Spector TD (2018) Role of the gut microbiota in nutrition and health. BMJ (Clinical research ed.) 361:k2179. https://doi.org/10.1136/bmj.k2179

Vandevoorde K, Ducreux S, Bosch A, Guillaud O, Hervieu V, Chambon-Augoyard C, Poinsot D, André P, Scoazec JY, Robinson P, Boillot O, Dubois V, Dumortier J (2018) Prevalence, risk factors, and impact of donor-specific alloantibodies after adult liver transplantation. Liver Transpl 24:1091-1100. https://doi. org/10.1002/lt.25177

Varma S, Stéphenne X, Komuta M, Bouzin C, Ambroise J, Smets F, Reding R, Sokal EM (2017) The histological quantification of alpha-smooth muscle actin predicts future graft fibrosis in 
pediatric liver transplant recipients. Pediatr Transpl. https://doi. org/10.1111/petr.12834.10.1111/petr.12834

Venturi C, Sempoux C, Quinones JA, Bourdeaux C, Hoyos SP, Sokal E, Reding R (2014) Dynamics of allograft fibrosis in pediatric liver transplantation. Am J Transpl 14:1648-1656. https://doi. org/10.1111/ajt.12740

Verbeke L, Mannaerts I, Schierwagen R, Govaere O, Klein S, Vander Elst I, Windmolders P, Farre R, Wenes M, Mazzone M, Nevens F, van Grunsven LA, Trebicka J, Laleman W (2016) FXR agonist obeticholic acid reduces hepatic inflammation and fibrosis in a rat model of toxic cirrhosis. Sci Rep 6:33453. https://doi. org/10.1038/srep33453

Voutilainen SH, Kosola SK, Tervahartiala TI, Sorsa TA, Jalanko HJ, Pakarinen MP (2017) Liver and serum expression of matrix metalloproteinases in asymptomatic pediatric liver transplant recipients. Transpl Int 30:124-133. https://doi.org/10.1111/tri.12879

Vrieze A, Van Nood E, Holleman F, Salojärvi J, Kootte RS, Bartelsman JF, Dallinga-Thie GM, Ackermans MT, Serlie MJ, Oozeer R, Derrien M, Druesne A, Van Hylckama Vlieg JE, Bloks VW, Groen AK, Heilig HG, Zoetendal EG, Stroes ES, de Vos WM, Hoekstra JB, Nieuwdorp M (2012) Transfer of intestinal microbiota from lean donors increases insulin sensitivity in individuals with metabolic syndrome. Gastroenterology 143:913-916. https ://doi.org/10.1053/j.gastro.2012.06.031 (e7)

Wang YD, Chen WD, Wang M, Yu D, Forman BM, Huang W (2008) Farnesoid $\mathrm{X}$ receptor antagonizes nuclear factor kappaB in hepatic inflammatory response. Hepatology 48:1632-1643. https ://doi.org/10.1002/hep.22519

Wang HB, Wang PY, Wang X, Wan YL, Liu YC (2012) Butyrate enhances intestinal epithelial barrier function via up-regulation of tight junction protein Claudin-1 transcription. Dig Dis Sci 57:3126-3135. https://doi.org/10.1007/s10620-012-2259-4

Wang Y, Gao X, Zhang X, Xiao Y, Huang J, Yu D, Li X, Hu H, Ge T, Li D, Zhang T (2019) Gut microbiota dysbiosis is associated with altered bile acid metabolism in infantile cholestasis. mSystems. https://doi.org/10.1128/msystems.00463-19

Wang J, Qian T, Jiang J, Yang Y, Shen Z, Huang Y, Chen G, Zheng S, Dong R (2020a) Gut microbial profile in biliary atresia: a casecontrol study. J Gastroenterol Hepatol 35:334-342. https://doi. org/10.1111/jgh. 14777

Wang X, Chen L, Wang H, Cai W, Xie Q (2020b) Modulation of bile acid profile by gut microbiota in chronic hepatitis B. J Cell Mol Med 24:2573-2581. https://doi.org/10.1111/jcmm.14951

Weinstock GM (2012) Genomic approaches to studying the human microbiota. Nature 489:250-256. https://doi.org/10.1038/natur e11553

Weitkunat K, Stuhlmann C, Postel A, Rumberger S, Fankhänel M, Woting A, Petzke KJ, Gohlke S, Schulz TJ, Blaut M, Klaus S, Schumann S (2017) Short-chain fatty acids and inulin, but not guar gum, prevent diet-induced obesity and insulin resistance through differential mechanisms in mice. Sci Rep 7:6109. https ://doi.org/10.1038/s41598-017-06447-x

Workman MJ, Gleeson JP, Troisi EJ, Estrada HQ, Kerns SJ, Hinojosa CD, Hamilton GA, Targan SR, Svendsen CN, Barrett RJ (2018) Enhanced utilization of induced pluripotent stem cell-derived human intestinal organoids using microengineered chips. Cell Mol Gastroenterol Hepatol 5:669-677. https://doi.org/10.1016/j. jcmgh.2017.12.008 e2

Wu W, Lv L, Shi D, Ye J, Fang D, Guo F, Li Y, He X, Li L (2017) Protective effect of Akkermansia Muciniphila against immunemediated liver injury in a mouse model. Front Microbiol 8:1804. https://doi.org/10.3389/fmicb.2017.01804

Xie Y, Chen H, Zhu B, Qin N, Chen Y, Li Z, Deng M, Jiang H, Xu X, Yang J, Ruan B, Li L (2014) Effect of intestinal microbiota alteration on hepatic damage in rats with acute rejection after liver transplantation. Microb Ecol 68:871-880. https://doi org/10.1007/s00248-014-0452-z

Yamada H, Kondou H, Kimura T, Ikeda K, Tachibana M, Hasegawa Y, Kiyohara Y, Ueno T, Miyoshi Y, Mushiake S, Ozono K (2012) Humoral immunity is involved in the development of pericentral fibrosis after pediatric live donor liver transplantation. Pediatr Transpl 16:858-865. https://doi.org/10.111 1/j.1399-3046.2012.01781.x

Yang CH, Perumpail BJ, Yoo ER, Ahmed A, Kerner JA Jr (2017) Nutritional needs and support for children with chronic liver disease. Nutrients 9:1127. https://doi.org/10.3390/nu9101127

Yanguas SC, Cogliati B, Willebrords J, Maes M, Colle I, van den Bossche B, de Oliveira C, Andraus W, Alves VAF, Leclercq I, Vinken M (2016) Experimental models of liver fibrosis. Arch Toxicol 90:1025-1048. https://doi.org/10.1007/s00204-015-1543-4

Yuan J, Chen C, Cui J, Lu J, Yan C, Wei X, Zhao X, Li N, Li S, Xue G, Cheng W, Li B, Li H, Lin W, Tian C, Zhao J, Han J, An D, Zhang Q, Wei H, Zheng M, Ma X, Li W, Chen X, Zhang Z, Zeng H, Ying S, Wu J, Yang R, Liu D (2019) Fatty liver disease caused by high-alcohol-producing klebsiella pneumoniae. Cell Metab 30:1172. https://doi.org/10.1016/j.cmet.2019.11.006

Zhang R (2018) Donor-specific antibodies in kidney transplant recipients. Clin J Am Soc Nephrol 13:182-192. https://doi. org/10.2215/CJN.00700117

Zhu L, Baker SS, Gill C, Liu W, Alkhouri R, Baker RD, Gill SR (2013) Characterization of gut microbiomes in nonalcoholic steatohepatitis (NASH) patients: a connection between endogenous alcohol and NASH. Hepatology 57:601-609. https://doi.org/10.1002/ hep.26093

Publisher's Note Springer Nature remains neutral with regard to jurisdictional claims in published maps and institutional affiliations. 